\title{
Reframing Corporate Subjectivity: Systemic Inequality and the Company at the Intersection of Race, Gender and Poverty
}

\author{
Charmika Samaradiwakera-Wijesundara* (1) \\ University of the Witwatersrand Johannesburg, Faculty of Commerce, Law and Management, \\ South Africa and International Institute of Social Studies, Hague, The Netherlands \\ *Corresponding author. Email: Charmika.Wijesundara@wits.ac.za
}

\begin{abstract}
In this paper I use South Africa as a reference point to discuss the company as a juristic person and its relationship to natural persons through the concepts of subjectivity and personhood. I do this in an attempt to reveal that granting of juristic personality as 'the company' is not a neutral, organic or inevitable product of the law and economy but a construct symbiotically bound to the colonial state. Underlying this juristic personhood is colonial ideology which perpetuates racialized and gendered poverty and inequality as systemic oppression, in order to deliberately facilitate and maintain conditions of domination and exploitation. Rather than taking the conventional business and human rights starting point that accepts the corporate structure without critique, it is argued that by reorienting away from juristic personality as purportedly 'neutral' and reframing the construct, the powers of the company might be curtailed, thereby interrupting these continuing colonial logics.
\end{abstract}

Keywords: decolonial; feminist theory; gender; legal personality; race; South Africa; systemic inequality

\section{Background and Introduction: Beginning at the Very Beginning}

It is trite that corporations have immense power that sometimes rivals that of states. ${ }^{1}$ It is also trite that they impact virtually every aspect of our daily lives, directly or indirectly. ${ }^{2}$ The result is that the "capabilities of corporations to do good and evil are enormous and their capacity to cause different types of harm is limitless'. ${ }^{3}$ This power is understood to rest with the corporation as a legal person, and not with the human actors through whom the power is exercised. ${ }^{4}$ Juristic

\footnotetext{
${ }^{1}$ Mordechai Kremnitzer, 'A Possible Case for Imposing Criminal Liability on Corporations in International Criminal Law’ (2010) 8 Journal of International Criminal Justice 909.

2 Paul O'Connell, 'Brave New World?: Human Rights in the Era of Globalisation' in Mansuli Ssenyonjo and Mashood A Baderin (eds.), International Human Rights Law: Six Decades after the UDHR and Beyond (Surrey: Ashgate Publishing Company, 2010) 195, 202.

${ }^{3}$ Kremnitzer, note 1, 910.

4 John Dewey, 'The Historic Background of Corporate Legal Personality' (1926) 35:6 The Yale Law Journal 655, 656; Frederic W Maitland, 'Moral Personality and Legal Personality' (1905) 6:2 Journal of the Society of Comparative Legislation 192, 195; Sigmund Timberg, 'Corporate Fictions: Logical, Social and International Implications' (1946) 46:4 Columbia Law Review 533.
}

(c) The Author(s), 2022. Published by Cambridge University Press. This is an Open Access article, distributed under the terms of the Creative Commons Attribution licence (http://creativecommons.org/licenses/by/4.0), which permits unrestricted re-use, distribution and reproduction, provided the original article is properly cited. 
personality means that, while a corporation 'has neither a body to be kicked nor [a] soul to be damned, it is a person for the purposes of the law. ${ }^{5}$ Corporations exist purely because the law allows them to be constructed. ${ }^{6}$ It is by an act of legal imagination that these hugely powerful (legal) persons come into being.

There are consistent efforts to manage or mitigate corporate power so that their activities cause less harm to human beings. These initiatives take the form of criminal liability (directed against the juristic person or indirectly against company organs), civil liability (delicts/torts), administrative penalties, ${ }^{7}$ and calls for transformative remedies and enforcement mechanisms for human rights violations. ${ }^{8}$ What remains consistent in these approaches is that they depart from the assumption that companies - in their current form - are here to stay.

I contend that interrogating the legitimacy of the existence of the company as a (legal) person and what this recognition facilitates, is fundamental to ensuring accountability for the harms they cause and are empowered to cause. In order to interrogate this proposition it is useful to consider what the company means in the context of this paper. I do not suggest that companies are homogenous; there are variations in types, size and footprint; specificities of incorporation; and jurisdictional operation. I do, however, contend that there is characteristic similarity that allows us to identify the company as a coherent concept. This feature requires us to view the company as distinct from any animating human energy. That is the juristic personality of the company that renders it a (legal) person and enables it to engage in legal intercourse with other legal subjects. ${ }^{9}$

The theories of juristic personality provide some description of how juristic persons come into 'being'. Nonetheless, they fall short of answering the questions of what the nature of the juristic person is, and what the purpose of granting its existence is. The short answer appears to be that the company as juristic person is what the law says it is. ${ }^{10}$ This provokes questions: why would the law allow for the existence of a distinct person from the human beings that animate it; and who defines the law, i.e., who gets to decide that the company exists and what is their motivation for that existence?

This is not an abstract theoretical debate - but one with real consequences for human beings. ${ }^{11}$ In the words of Deiser: 'What the legislator finds before him is men, individuals, citizens, either isolated or in groups, and, when his law is unjust, it is no imaginary person that suffers. ${ }^{12}$ To place this in perspective: all the debates on company power and its

\footnotetext{
${ }^{5}$ Lord Chancellor Baron Thurlow, 'Introduction to the New Companies Act: General Overview of the Act' in Farouk HI Cassim and Maleka Femida Cassim (eds.), Contemporary Company Law, 2nd edn (Cape Town:Juta \& Co, 2012) 1,31 .

${ }^{6}$ Dewey, note 4, 655.

${ }^{7}$ Kremnitzer, note 1, 910.

${ }^{8}$ Erika R George, 'The Enterprise of Empire: Evolving the Understandings of Corporate Identity and Responsibility' in Jena Martin and Karen E Bravo (eds.), The Business and Human Rights Landscape: Moving Forward, Looking Back (Cambridge: Cambridge University Press, 2016) 19, 50; Meetali Jain and Bonita Meyersfeld, 'Lessons from Kiobel v Royal Dutch Petroleum Company: Developing Homegrown Lawyering Strategies around Corporate Accountability’ (2014) 30:3 South African Journal on Human Rights 430, 453, 457.

${ }^{9}$ For a discussion of this principle, see Salomon v A Salomon \& Co Ltd [1896] UKHL 1, 35, 57; Dewey, note 4, 673; Paddy Ireland, 'Limited Liability, Shareholder Rights and the Problem of Corporate Irresponsibility' (2010) 34 Cambridge Journal of Economics 837, 839; Robert Penington, 'Origin of Corporations' (1931) 2 Corporate Practice Review 33, 36; PQR Boberg, The Law of Persons and The Family (Cape Town: Juta \& Co, 1999) 3; CJ Jordaan and RA Davel, The Law of Persons (Cape Town: Juta \& Co, 2005) 5; Dewey, note 4, 655.

${ }^{10}$ Dewey, note 4, 655.

11 George F Deiser, 'The Juristic Person II' (1909) 57:4 University of Pennsylvania Law Review and American Law Register 216, 228-9.

12 Ibid, 231.
} 
excesses revolve around an entity that is a construct of the law and operates as a fiction: a made-up entity.

The company as a (legal) person ostensibly acts in its own interests that have been articulated as primarily profit maximization..$^{13}$ Notwithstanding this, it is ultimately for the interests of real human beings. ${ }^{14}$ I wish to complicate this consideration with the observation that the company is not simply a neutral vehicle, but a repository of power that simultaneously obfuscates its instrumentality in systemic racial and gendered oppression while presenting as a morally neutral profit-seeking actor. In this way, it shields otherwise implicated human actors from accountability while allowing them to syphon benefit and displace risk/harm onto vulnerable members of society - the oppressed that it has systematically rendered vulnerable. ${ }^{15}$

I have argued that the company is an instrument of coloniality made in the image of the sovereign as a representative of God on earth, later replaced by Enlightenment man. ${ }^{16}$ This allowed personhood to the exclusion of those that did not meet the criteria decided by such men. Personhood was used to relegate to non-human status and justify the subjugation of those excluded from the category of person. This exclusion was fundamentally on the basis of race. ${ }^{17}$ This took place in the context of a global economic system that, designed and developed through processes of European conquest and colonialism, has been described as foundationally racist, patriarchal and classist. ${ }^{18}$ What is crucially missing from this argument is that gender is inextricably implicated in race and the subjectivity that precipitates the concept of the (legal) person.

Pumla D Gqola reflects on 'how slavery is evoked and remembered as part of negotiating current ways of being'; ${ }^{19}$ how language functions politically in the 'post-apartheid' imagination in 're-memorying' identities. ${ }^{20}$ In this process the linear conception of time attached to narratives of Enlightenment and colonial advancement are challenged through the workings of memory that 'recogn[ize] that history is always fictional' and contingent. ${ }^{21}$ This would invite the interrogation of so-called conventional wisdom of the company as a (legal) person.

Since language is embedded with meaning, as the law is with ideology, simply altering the use of language does not transform the fact that it is implicated in global dynamics of power, and that the past is an ever-present spectre that silhouettes selfhood. ${ }^{22}$ I would extend this literally to the fiction of the (legal) person of the company. Therefore, the call to be 'self-consciously excavatory' when considering (slave) memory suggests that it would be

\footnotetext{
${ }^{13}$ Douglas G Baird and M Todd Henderson, 'Other People’s Money' (2008) 60:1 Stanford Law Review 1309, 1323-4; Milton Friedman, Capitalism and Freedom (Toronto: University of Toronto Press, 1962) 112.

${ }^{14}$ Morgan Ndlovu and Eric N Makoni, 'The Globality of the Local? A Decolonial Perspective on Local Economic Development in South Africa' (2014) 29:4-5 Local Economy 503, 512; Stephanie Blankenburg, Dan Pelsch and Frank Wilkinson, 'Limited Liability and the Modern Corporation in Theory and Practice' (2010) 34 Cambridge Journal of Economics 821, 821, 830 .

${ }^{15}$ Katharina Pistor, The Code of Capital (Princeton: Princeton University Press, 2019) 65.

${ }^{16}$ Charmika Samaradiwakera-Wijesundara, 'The Fiction of the Juristic Person: Reassessing Personhood in Relation to People' in Melissa Steyn and William Mpofu (eds.), Decolonising the Human: Reflections from Africa on Difference and Oppression (Johannesburg: Wits University Press, 2021) 186, 196.

${ }^{17}$ Ibid, 194-6.

18 Anibal Quijano, 'Coloniality of Power, Eurocentrism, and Latin America' (2000) 1:3 Nepantla: Views from South 533, 555; bell hooks, Feminist Theory from Margin to Centre (Boston: South End Press, 1984) 28, 48.

${ }^{19}$ Pumla D Gqola, What Does Slavery Mean to Me?: Postcolonial/Slave Memory in Post-Apartheid South Africa (New York: New York University Press, 2010) 1.

${ }^{20}$ Ibid, 6.

${ }^{21}$ Ibid, 7.

${ }^{22}$ Desirée Lewis, 'African Gender Research and Postcoloniality: Legacies and Challenges', paper presented at the Codesria Conference on Gender in the New Millenium, Cairo, 7-10 April 2002.
} 
prudent to interrogate not only the impact of the company as a (legal) person and how to manage its consequences, but its very essence. ${ }^{23}$

I argue that a concern with holding corporations accountable for human rights violations, and particularly one rooted in an intersectional gendered approach, should begin with an evaluation of (legal) personality and the legitimate parameters of company power. In other words, before even considering how company power should be managed and mitigated, we should consider whether it should exist in the way it does. If it is brought into existence through the law, it can be curtailed by the law if the will exists. This fundamentally shifts the dynamics of power from one where a concession is sought from companies to guard against human (rights) violations; to one where the very access to and exercise of power must be justified relative to actual human rights violations whether deemed present or historical. ${ }^{24}$

In this paper, situating my analysis in South Africa, I systematically unpack this argument by first outlining the basis for connecting the recognition of the (legal) personality of the company to intersectional systemic oppression. In this process, I articulate why temporalities and context matter in telling the history of the company and its identity formation; by showing how oppression extends to the systemic installation of poverty and inequality. I demonstrate that this is specifically gendered and racialized, and that these intersecting forms of oppression are incorporated into the very design of the company, which is rooted in colonial-apartheid ideologies. Having painted this picture, I return to the nature of the company as a juristic person and how, as a purportedly 'neutral' instrument, it obscures the accountability of the human actors responsible for, and who ultimately benefit from, company power while displacing risk and harm onto society.

\section{The Subject(ivity) of Systemic Inequality}

Sylvia Tamale argues that the co-constituting nature of race and gender must be appreciated using an intersectional analysis as, "[s]ystems of oppression do not operate separately along a single axis (e.g., race) but work simultaneously, shaping each other interactively'. ${ }^{25}$ In addressing this complexity rather than avoiding it, Tamale calls for an approach to social justice that transcends binaries and explores different conceptions of the relationship between human beings and the world. ${ }^{26}$

A central tenet of African Feminist theory is the issue of inter-subjectivity and defining who has the authority to name and determine the content of subjectivity. ${ }^{27}$ This is apparent in calls to critically interrogate the framing of the proposed solutions to systemic inequality. In Tamale's words, '[t]he individualistic notion of equality assumes a default value, some standard against which equality can be measured. Not only is the comparator masculine but he is also White, middle-class, able-bodied, Christian and heterosexual.' ${ }^{28}$ The masculine nature of the law exposes how, "under liberalism, the law creates legal rights such as "equality" to allow for separate, atomistic competing individuals to pursue their own

\footnotetext{
${ }^{23}$ Gqola, note 19, 201.

${ }^{24}$ This is consistent with UNGP 3 which requires that states 'Ensure that other laws and policies governing the creation and ongoing operation of business enterprises, such as corporate law, do not constrain but enable business respect for human rights'. I am indebted to the reviewer who made a link between the arguments proposed and UNGP 3.

${ }^{25}$ Sylvia Tamale, Decolonization and Afro-Feminism (Ottawa: Daraja Press, 2020) 63-5.

${ }^{26}$ Ibid, 212.

27 Pumla D Gqola, 'Ufanele Uqavile: Blackwomen, Feminisms and Postcoloniality in Africa' (2001) 16:50 African Feminisms 11; Desiree Lewis, 'Introduction: African Feminisms' (2001) 16:50 African Feminisms 4-5.

${ }^{28}$ Tamale, note $25,213$.
} 
interests and to protect them from the interference of other individuals. ${ }^{29}$ This produces a dynamic where deviation from the parameters of the legally recognized subject forecloses the possibility of legal protections. ${ }^{30}$

Tamale's analysis of subjectivity and its gendered consequences is consistent with bell hooks' concerns around defining the aim of feminism as simply the equality between men and women. ${ }^{31}$ She argues that feminism must focus on ending sexist oppression, and necessarily encompasses confronting and eliminating racial and class oppressions. ${ }^{32}$ Assimilation into a privileged category (or subjectivity) does not solve the problem of systemic oppression and its consequences. ${ }^{33}$ In the South African context, this is consistent with Tshepo Madlingozi's thesis that colonial-apartheid creates an ontology of being where being white is equated to being human and greater than being black which is equated to being sub-human. ${ }^{34}$ Society becomes bifurcated to allow elite black people to assimilate into putative white status and approximate whiteness; while the majority of the black population remains outside democratic constitutional society that enjoys the human rights and freedoms that define South Africa's constitutional democracy. ${ }^{35}$ This may also account for what Desiree Lewis describes as the paradox of continued violence, poverty and inequality despite South Africa's suite of progressive legislation and policies following the inclusion of a justiciable Bill of Rights in the Constitution. ${ }^{36}$

Narrating a picture of this reality requires emphasizing specific dimensions of the origins of the continued racialized and gendered poverty and inequality ('systemic inequality') in South Africa. In framing the problem, Joel M Modiri's contention, '[w]hat is important is not who constitutes the capitalist class, but who constitutes the large majority of the poor, unemployed and working class (viz Blacks)' is illuminating. ${ }^{37}$ This may be evidenced by the extent of national discontent as demonstrated by the number of protests in South Africa which are said to be the highest in the world. ${ }^{38}$ The scale and nature of the protests have moved from being describable as a 'rebellion' in 2010 to a 'revolt' in 2018, which is depicted in the national unrest that received global media attention in 2021.39

This poverty and inequality has been documented as identifiably racialized and gendered. In a joint study by the Department of Planning, Monitoring and Evaluation (DPME), Statistics South Africa and the World Bank, it is reported that 'South Africa is the most unequal

29 Ibid.

30 Tamale, note $25,213$.

31 bell hooks, note 18,28 .

32 Ibid.

33 Ibid.

${ }^{34}$ I do not take race, or any other identity, to be essential or immutable. In recognizing the various contextual iterations of racial identity, I refer here to the conception of Blackness following the Black Consciousness Movement. See Steve Biko, I Write What I Like (Johannesburg: Picador Africa, 2004). Similarly, I do not operate from an essentialist conception of gender and recognize that these terms have varied meanings across times and contexts. As I evoke them I am aware of the limitations inherent in any evocation. In keeping with this 'I write from the limits of myself' and see these limits as transient as articulated by Maria Lugones, Pilgrimages/Peregrinajes: Theorizing Coalition Against Multiple Oppressions (Lanham: Md Rowman \& Littlefield, 2003) 109.

${ }^{35}$ Tshepo Madlingozi, 'Social Justice in a Time of Neo-Apartheid Constitutionalism: Critiquing the Anti-Black Economy of Recognition, Incorporation and Distribution' (2016) 1 Stellenbosch Law Review 123, 124, 128-9.

${ }^{36}$ Constitution of the Republic of South Africa 1996; Desiree Lewis, 'Governmentality and South Africa's Edifice of Gender and Sexual Rights' (2021) 56:1 Journal of Asian and African Studies 109, 112.

37 Joel M Modiri, 'Law’s Poverty' (2015) 18:2 Potchefstroom Electronic Law Journal 224, 232.

${ }^{38}$ Peter Alexander, 'Rebellion of the Poor: South Africa's Service Delivery Protests - A Preliminary Analysis' (2010) 37:123 Review of African Political Economy 25, 27.

${ }^{39}$ Ibid, 40; 'South Africa Unrest Death Toll Jumps to More Than 300', Al Jazeera (22 July 2021), https://www.alja zeera.com/news/2021/7/22/south-africa-unrest-death-toll-jumps-to-more-than-300 (accessed 16 November 2021). 
country in the world by any measure.' ${ }^{40}$ The study notes '[r]ace is a strong predictor of poverty' and that black people make up the majority of the 'chronically poor'; 41 'race has become the main factor determining inequality of opportunity' in respect of access to education and employment; ${ }^{42}$ and gender and race account for the fact that black women disproportionately constitute the impoverished. ${ }^{43}$ This echoes Oxfam's report that South Africa is one of the most unequal countries in the world, with highly gendered inequalities, based on income distribution. ${ }^{44}$

Poverty as it now manifests is not an inevitable or accidental phenomenon, but is systemic and rooted in colonial history. ${ }^{45}$ While the origin of this systemic inequality has been attributed to apartheid, ${ }^{46}$ Madlingozi and Sanele Sibanda agree that these protests are manifestations of resistance to the state's continuation of colonial-apartheid neoliberal socio-economic policy and practice that continue to incubate systemic poverty and inequality. ${ }^{47}$ As such, "[w]hile the laws of the country have changed considerably, the architecture, framework and logic of colonialism-apartheid remains. ${ }^{48}$ In other words, the problem has a long-term context that is broader than apartheid. Moreover, based on the prevailing picture of poverty and inequality, it does not appear that the advent of South Africa's constitutional democracy in 1994 radically altered this trajectory.

While poverty and inequality can be articulated as human rights violations ${ }^{49}$ they have deeper implications for subjectivities that extend beyond the material to influence psycho-social relations. ${ }^{50}$ This is evident in poverty's impact on 'culture, epistemology, and social power, the division of labour, decision-making procedures, autonomy and agency. ${ }^{51}$ In other words, experiences of poverty and inequality determine whether one

\footnotetext{
${ }^{40}$ National Planning Commission Secretariat at the Department of Planning, Monitoring and Evaluation (DPME), Statistics South Africa and the World Bank, 'Overcoming Poverty and Inequality in South Africa: Assessment of Drivers, Constraints and Opportunities' (2018), https://documents1.worldbank.org/curated/en/530481521735906534/ pdf/124521-REV-OUO-South-Africa-Poverty-and-Inequality-Assessment-Report-2018-FINAL-WEB.pdf (accessed 16 November 2021) (DPME Report) 60.

${ }^{41}$ Ibid, 38 .

42 Ibid, 66

${ }^{43}$ Ibid, $14-16$.

${ }^{44}$ Oxfam, 'Inequality in South Africa: A Two Part Document on the Current Understanding \& Dimensions of Inequality in Health, Gender and Livelihoods' (2014), https://oxfamilibrary.openrepository.com/bitstream/han dle/10546/322516/rr-inequality-south-africa-010714-en.pdf;jsessionid=344EEED7B945ACD03592E2DE443EB1C5? sequence $=1$ (accessed 16 November 2021) 7, 9 .

${ }^{45}$ Thomas Pogge, 'Recognized and Violated by International Law: The Human Rights of the Global Poor' (2005) 18:4 Leiden Journal of International Law 717, 723.

${ }^{46}$ DPME, note 40, xiv; Oxfam, note 44, 7.

${ }^{47}$ Sanele Sibanda, "'Not Yet Uhuru" - The Usurpation of the Liberation Aspirations of South Africa's Masses by a Commitment to Liberal Constitutional Democracy', PhD thesis, University of the Witwatersrand (21 November 2018), https://www.academia.edu/41660151/_Not_Yet_Uhuru_The_Usurpation_of_the_Liberation_Aspirations_of_South_ Africas_Masses_by_a_Commitment_to_Liberal_Constitutional_Democracy_PhD_thesis (accessed 16 November 2021) 15; Tshepo Madlingozi, 'Mayibuye iAfrika? Disjunctive Inclusions and Black Strivings For Constitution and Belonging in South Africa', PhD thesis, University of London (2018), https://www.academia.edu/37502826/Mayibuye_iAfrika_ Disjunctive_Inclusions_and_Black_Strivings_for_Constitution_and_Belonging_in_South_Africa (accessed 16 November 2021).

${ }^{48}$ Modiri, note 37, 225 (emphasis retained).

${ }^{49}$ United Nations Declaration on Human Rights, 217 A (III) (10 December 1948), arts 25(1) and 28; Thomas Pogge, World Poverty and Human Rights, 2nd edn (Cambridge: Polity, 2008) 176 cited in Gwilym D Blunt, 'Is Global Poverty a Crime Against Humanity?' (2015) 7:3 International Theory 539, 541; Bonita Meyersfeld, Committing the Crime of Poverty: The Next Phase of the Business and Human Rights Debate (Cambridge: Cambridge University Press, 2017) 173, 174.

${ }^{50}$ Wendy Brown, Left Legalism/Left Critique (London: Duke University Press, 2002); Modiri, note 37, 227.

${ }^{51}$ Modiri, note 37, 228.
} 
enjoys human status at all, and (legal) personhood in a real sense. Mapping moments in the company's history in South Africa exposes this connection and reveals the implications of the continued recognition of the (legal) personhood of the company.

\section{Systemic Inequality: A Product of the Colonial Company}

While the colonization of South Africa is attributed to the Dutch in 1652, it was executed by the Dutch East India Company (DEIC) which, under Dutch law, was an independent legal person. ${ }^{52}$ The DEIC was a chartered company with juristic personality granted as a privilege by the state of Holland, designed and deployed to further colonial interests. Grotius' extrapolations on juristic personality (that is the legal personality of the company) and the right of conquest provided legal justification for the DEIC to act as both a business and as a sovereign in the territory of the Cape Colony. ${ }^{53}$ The DEIC executed this by imposing an all-encompassing colonial administration, military force, commercial infrastructure and a legal system. ${ }^{54}$ This facilitated the appropriation of territory as well as forcing indigenous peoples into either slave labour or into a monetized labour system controlled through coercion in the form of tax or force. ${ }^{55}$ In this process, the DEIC introduced and maintained deliberate social hierarchies..$^{56}$ This is significant as the DEIC was legally sanctioned, by Holland, to install the South African legal system, which was based on white-supremacy, patriarchy, the sovereign militarized nation state, capitalist modes of production and Roman-Dutch Law.

The DEICs silence on the gendered dynamic of social relations at the time ${ }^{57}$ is explained by the fact that colonized peoples were granted sex as a putatively reproductive function. ${ }^{58}$ As such, colonized peoples were distinguished according to reproductive capacity as animate objects would be, but not recognized as gendered for the purposes of socially constructed identities as other humans were. Archival records also described enslaved peoples in proprietary terms. Nigel Worden remarks that 'silence in the [DEIC] paper empire in relation to slave lives and histories ... has been scrutinised not only for what it seems to yield with ease, but also for that which it cannot communicate. ${ }^{59}$ Helen Bradford describes how the texts on the DEIC generally moved from 'male particular to the human universal'. ${ }^{60}$ This too is a pattern that emerges in historical accounts of South Africa: the erasure of black women. ${ }^{61}$

The figurehead of the DEIC in 1652 was Jan van Riebeck, the company surgeon who subsequently became Governor of the Cape Colony. ${ }^{62}$ The colonial state as juristic person was legitimated by the colonial company and the overlap of interests can be seen in its

\footnotetext{
${ }^{52}$ Peter Reynders and Rupert Gerritsen, 'A Translation of the Charter of the Dutch East India Company: Granted by the States General of the United Netherlands, 20 March 1602', Australia on the Map Division of the Australasian Hydrographic Society (2011), http://rupertgerritsen.tripod.com/pdf/published/VOC_Charter_1602.pdf (accessed 16 November 2021); M S Geen, The Making of the Union of South Africa (London: Longmans, Green, 1947), 7.

${ }^{53}$ Gavin Lucas, An Archaeology of Colonial Identity: Power and Material Culture in the Dwars Valley, South Africa (New York: Springer, 2006) 32.

${ }^{54}$ Ibid, 32.

${ }^{55}$ Ibid, 72.

${ }^{56}$ Ibid, 32

${ }^{57}$ Nigel Worden, 'Cape Slaves in the Paper Empire of the VOC' (2014) 40 Kronos 22, 44.

${ }^{58}$ Maria Lugones, ‘Toward a Decolonial Feminism' (2010) 25:4 Hypatia 742, 745.

${ }^{59}$ Worden, note $57,44$.

${ }^{60}$ Helen Bradford, 'Women, Gender and Colonialism: Rethinking the History of the British Cape Colony and its Frontier Zones, c. 1806-70’ (1996) 37 Journal of African History 351, 369.

${ }^{61}$ Simamkele Dlakavu, "'Say No, Black Woman”: The Giant is Falling and the Erasure of Black Women in South Africa' (2017) 31:3-4 Agenda 89, 90.

${ }^{62}$ Geen, note 52, 7.
} 
shared leader. The relationship between the state and the company that founded what became South Africa is significant. Anne McClintock argues that such colonial nation states were dependent on constructions of gender difference and hierarchy. ${ }^{63}$ Therefore, the company in colonial South Africa was not like any other person. It was literally parallel to the state and entrenched the concept of (legal) personality that authorized its own existence and that of the colony; while systematically legislating away colonized peoples' personhood.

This self-constituting act of statehood was followed by the imposition of a 'universalist' conception of citizenship and personhood that was anchored in the family unit. ${ }^{64}$ Paradoxically, the constructed family unit was central to the public configuration of the state but relegated to the realm of the private and installed the public/private dichotomy. ${ }^{65}$ The nation represented the family, yet the family was outside of the scope of the state. ${ }^{66}$ As such, women, as/like the categorically colonized, existed outside of history while white, middle-class men 'were seen to embody the forward-thrusting agency of national progress.' ${ }^{67}$

This demonstrates the installation of race, gender and class as three recurrent themes of Western colonialism and imperialism described by Mcclintock as the spread of white male subjectivity through domination of black female subjectivity (by way of objectification/ dehumanization); ${ }^{68}$ the imposition of a Western cultural episteme globally; and command of commodity capitalism. ${ }^{69}$ Thus, at the core of the colonial and imperial project of modernity is 'the conquest of the sexual and labor power of colonized women. ${ }^{70}$ Maria Lugones too, articulates the coloniality of gender by situating gender as historically contingent and instrumental rather than merely incidental to colonial conquest and subordination. ${ }^{71}$ This makes it necessary to recognize gender as a deliberate system used to subjugate. ${ }^{72}$ This revises the assumption that gender discriminations necessarily and always predate racial discrimination a-contextually and a-historically. ${ }^{73}$ It challenges the idea that gender can be accepted as a 'universal category/system ordering social life across times and cultures ${ }^{74}$ and renders visible the colonial hand in designing and implementing categories to control sexuality and subjectivity; and how in the process of indoctrination this has been internalized into the logics of many colonized peoples to the exclusion of other ways of being and relating between human beings. It is through this categorical and hierarchical social ordering that the DEIC caused a shift in not only the material, but the ontological condition of the indigenous and enslaved peoples. ${ }^{75}$ It transmogrified subjects into objects whose terms of existence it dictated. The DEIC exploited the persons that it rendered objectified.

\footnotetext{
63 Anne McClintock, Imperial Leather: Race, Gender and Sexuality in The Colonial Contest (New York: Routledge, 1995) 353.

${ }^{64}$ Ibid, 357.

${ }^{65}$ Ibid.

66 Ibid.

67 Ibid, 360.

${ }^{68}$ Kenneth B Nunn, 'Law as a Eurocentric Enterprise' (1997) 15:2 Law and Inequality: A Journal of Theory and Practice 323.

${ }^{69}$ McClintock, note 63, 2-3.

70 Ibid, 3.

${ }^{71}$ Maria Lugones, 'The Coloniality of Gender' (2008) 2:2 Worlds \& Knowledges Otherwise 1.

72 Rosalba Icaza and Rolando Vázquez, 'The Coloniality of Gender as a Radical Critique of Developmentalism' in Wendy Harcourt (ed.), The Palgrave Handbook of Gender and Development: Critical Engagements in Feminist Theory and Practice (New York: Palgrave Macmillan, 2016) 62, 66.

${ }^{73}$ Ibid.

74 Ibid.

${ }^{75}$ Magobe B Ramose, 'In Memoriam: Sovereignty and the “New” South Africa' (2007) 16:2 Griffith Law Review 310, 319.
} 
The move from imperial to state sovereignty, in the form of the Union of South Africa, incorporated in 1910, marked a shift in the seat of authority for granting juristic personality to a company by charter. It did not mark change either to the law or underpinning ideology attached to legal personality. Later incorporation of a company through compliance with legislated formalities, rather than by state decreed charter, was made possible. Despite this laden history, a contemporary South African government publication uncritically states 'Company law has existed in South Africa since 1861' citing company law in the Cape Colony. ${ }^{76}$

The stated aim of the introduction of the first Companies Act in South Africa was to make the privilege of the company more 'widely accessible'. ${ }^{77}$ Nonetheless, the company as it existed and operated in South Africa continued to be used to further the imposed racialized and gendered order of domination. Mike Morris explains how the first pass laws were introduced by the state as a means of controlling black mine labour for companies in the early 1890 s. $^{78}$ Pass laws required black people to carry pass books and restricted movement outside racially designated areas for authorized purposes only. He maintains that the 1913 Natives Land Act ${ }^{79}$ was not simply an ideological move to racially segregate but one calculated to pressurize remaining black subsistence farmers to become a consistent source of migrant labour for white mining, farming and manufacturing interests. ${ }^{80}$ Similarly, Sampie Terreblanche argues that the strategy behind the 1913 Native Land Act was developed by the companies comprising the 'Mineral Energy Complex' that was responsible for the appointment of the commission tasked with determining why black people were not taking up employment in the mines. ${ }^{81}$ This is significant to understanding (legal) personhood of the company - as they were instrumental in the design and implementation of legislation and policy in the furtherance of exploitative colonial interests.

While migrant labour in the mines was largely taken up by black men, black women carried the continued labour in rural reserves thus subsidizing labour at the mines. ${ }^{82}$ Shireen Hassim describes this as 'a patriarchal bargain between chiefs and white capitalists in which male African labour would be provided and female productive and reproductive labour confined to the rural sphere. ${ }^{83}$ These chiefs served as tribal authorities, sanctioned selectively by the colonial administration, elaborating a customary law recorded by male colonial officials and articulated by male leaders. ${ }^{84}$ This is significant as it reminds us that conceptions of customary law were distorted through the capitalist colonial paradigm. This erased histories and foreclosed possibilities of relating beyond gender binaries and hierarchies as we now know them..$^{85}$ As urbanization expanded, the imposition of gender and attendant roles extended beyond slavery, sexual violence and forced reproduction,

\footnotetext{
${ }^{76}$ Department of Trade and Industry, 'South African Company Law for the 21st Century: Guidelines for Corporate Law Reform' (2004), https://www.gov.za/sites/default/files/gcis_document/201409/26493gen1183a.pdf (accessed 16 November 2021) 12.

${ }^{77}$ Ibid.

${ }^{78}$ Mike Morris, 'The Development of Capitalism in South Africa' in Martin J Murray (ed.), South African Capitalism and Black Political Opposition (Cambridge, MA: Schenkman Publishing Co., 1982) 39, 45.

${ }^{79}$ Natives' Land Act No. 27 of 1913 (South Africa).

${ }^{80}$ Morris, note 78, 52.

${ }^{81}$ Sampie Terreblanche, Lost in Transformation: South Africa's Search for a New Future Since 1986 (Johannesburg: KMM Review Publishing Company, 2012) 47.

${ }^{82}$ Shireen Hassim, 'Decolonising Equality: The Radical Roots of the Gender Equality Clause in the South African Constitution' (2018) 34:3 South African Journal on Human Rights 342, 349.

${ }^{83}$ Ibid.

${ }^{84}$ Martin Chanock, The Making of South African Legal Culture 1902-1936: Fear, Favour and Prejudice (Cambridge: Cambridge University Press, 2001) 23; Hassim, note 81, 344-5.

${ }^{85}$ Busangokwakhe Dlamini, 'Homosexuality in the African Context' (2006) 20:67 Agenda 128, 135.
} 
pressuring black women into the monetized economy and exploitative, low-paid work, including domestic work..$^{86}$

Throughout this process, juristic personality was racialized, based on majority holding and operation in the broader legal framework, and subject to laws applicable to race (erasing gender through the male universal). ${ }^{87}$ By holding that companies do not have a race, the Dadoo Ltd case confirmed the separation between the legal fiction that is the company and the natural persons who are invested in it. ${ }^{88}$ However, this separation was only recognized on appeal once the predecessor of the Natives Land Act $^{89}$ had been amended to prohibit black controlled companies owning land..$^{90}$ As such, the controlling interest of the company factually determined the race of the company. Companies operated with in a legislative framework that prevented black people from accessing the same privileges that white people had despite the purported neutrality of the instrument.

Women were not included in the definition of legal person, and in the case of Incorporated Law Society $v$ Wookey 1912 AD 623 the court held that this meant that they could not be appointed as attorneys. ${ }^{91}$ In contextualizing the reasoning behind this judgement, Catherine Albertyn draws out legal commentary at the time that framed the role of (white) women as 'bearing and nurture of the children of our race'. ${ }^{92}$ This position was altered when white women were permitted to join the legal profession in 1923 and granted the vote in 1930 , but this assimilation into the category of (legal) person and its attendant privileges was calculated by the state to dilute the limited conditional black male vote at the time to the total exclusion of black women. ${ }^{93}$ The prevailing racial inequality also meant that black women bore the social reproductive work, largely through domestic labour, that white women were liberated from by assimilation into the category of (legal) person. ${ }^{94}$

It has been argued that the motivation behind the policy of apartheid was ensuring conditions for increasing control over black labour for the purposes of economic exploitation. ${ }^{95}$ This was to meet the demands of white capital and the burgeoning industrialization of white South Africa while simultaneously protecting the interests, and securing the support, of the white working class that was facing increased competition from black labour. ${ }^{96}$ This included the deliberate destruction of subsistence in black communities in 'native reserves' of Bantustans and locations; and the intervention into 'tribal political institutions' and communal relations. ${ }^{97}$ This was with a view to entrenching the power dynamics that created and sustained this captive, exploitable migrant source of labour. ${ }^{98}$ This was a deliberately racialized and gendered process. ${ }^{99}$

\footnotetext{
${ }^{86}$ Hassim, note 82, 355.

${ }^{87}$ Dadoo Ltd and Others Appellants v Krugersdorp Municipal Council Respondents AD 530 (1920) 535-6.

88 Ibid.

${ }^{89}$ Law No. 3 of 1885 (South Africa) which was only repealed with the Abolition of Racially Based Land Measures Act No. 108 of 1991 (South Africa).

${ }^{90}$ Ibid, 549-50.

${ }^{91}$ Incorporated Law Society $v$ Wookey AD 623 (1912); Catherine Albertyn, 'Feminism and the Law' in Christopher Roederer and Darrell Moellendorf (eds.), Jurisprudence (Cape Town: Juta \& Co, 2004) 291, 297.

92 Albertyn, note 91, 298.

93 Cherryl Walker, Women and Resistance in South Africa (London: Onyx Press, 1982) 20; Albertyn, note 91, 297-8.

${ }^{94}$ Albertyn, note 91, 298.

95 Harold Wolpe, 'Capitalism and Cheap Labour Power in South Africa: From Segregation to Apartheid' in William Beinart and Saul Dubow (eds.), Segregation and Apartheid in Twentieth-Century South Africa (London: Routledge, 1995) $60,62-3$.

96 Ibid.

${ }^{97}$ Ibid, 63.

${ }^{98}$ Ibid, 63.

${ }^{99}$ McClintock, note 63, 324.
} 
According to Frederick A Johnstone, "[a]partheid" refers to the South African government's racial policies and ideology, while "white supremacy" refers to the overall power structure in South Africa, which is partially maintained by apartheid policies. ${ }^{100}$ Writing in 1970, he challenged the assertion at the time that industrialization and capitalist modes of production were contradictory to apartheid. Rather, he argued that the two aspirations were in fact mutually reinforcing on the basis of the racial power dynamics they perpetuated. This cannot be separated from gendered dynamics imposed on the labour of black women. That is, effectively, that white supremacy was the over-arching social organizer and that apartheid served these interests as much as capitalism did. ${ }^{101}$ This white supremacy is inextricably patriarchal. ${ }^{102}$

These social, political, commercial and legal underpinnings of the company appear not to have been upended by the transition into a constitutional democracy. In 1998, the South African Truth and Reconciliation Commission (TRC) explicitly recognized the role of companies during apartheid in engineering, benefiting from and maintaining colonial-apartheid systemic racialized (and inextricably gendered) oppression, ${ }^{103}$ despite companies asserting that they were amoral and therefore incapable of complicity or moral culpability. ${ }^{104}$ Nonetheless, companies fell outside the TRC's official mandate and no consequences followed. ${ }^{105}$

On the contrary, it appears that these companies transformed during the period of political transition into agents of progress and were viewed as the key to alleviation of poverty and inequality in South Africa's new constitutional democracy. ${ }^{106}$ Rather than an upending, what occurred was the affirmation of existing capitalist relations of power using neoliberal indicators as benchmarks to be achieved. ${ }^{107}$ This was enabled through the other key actor implicated in the colonial-apartheid legacy of South Africa - the state. This reading of events is supported by Sanele Sibanda's argument that former colonies are predisposed to maintaining colonial political, economic, legal, social and cultural institutions notwithstanding political independence. ${ }^{108}$ This is also consistent with Paul O'Connell's contention that nation-states at the moment of transition into independence from colonial administration are assimilated into neoliberal logics as a result of their positioning prior to independence. As such, "[t]he dominance of global capitalism and its complex suite of neoliberal policies and strategies compelled the newly democratised state to conform to the dictates of the market, which itself produces inequalities. ${ }^{109}$

In the absence of intervention, the perpetuation of systemic poverty and inequality in South Africa persists. The Marikana massacre of 16 August 2012 exposed the broader state of repression and resistance in the context of the exploitative conditions, amidst growing poverty and inequality, faced by workers and communities affected by mining in

\footnotetext{
${ }^{100}$ Frederick A Johnstone, 'White Prosperity and White Supremacy in South Africa Today' in Martin J Murray (ed.), South African Capitalism and Black Political Opposition (Cambridge, MA: Schenkman Publishing Co., 1982) 17, 38.

${ }^{101}$ Ibid, 33-4.

102 McClintock, note 63.

103 Truth and Reconciliation Commission, 'Truth and Reconciliation Commission of South Africa Report, Volume Four' (1998), https://www.justice.gov.za/trc/report/finalreport/Volume\%204.pdf (accessed 16 November 2021) para 161.

${ }^{104}$ Ibid, para 144.

${ }^{105}$ Nicoli Nattrass, 'The Truth and Reconciliation Commission on Business and Apartheid: A Critical Evaluation' (1999) 98 African Affairs 373, 381, 390-1.

106 Ibid.

107 Terreblanche, note 81, 63-71.

108 Sanele Sibanda, 'Not Purpose-Made! Transformative Constitutionalism, Post-Independence Constitutionalism and the Struggle to Eradicate Poverty’ (2011) 3 Stellenbosch Law Review 482, 495.

109 O'Connell, note 2, 207.
} 
South Africa, a sector that was long established in colonial-apartheid. ${ }^{110}$ In Bonita Meyersfeld's words, "[t]he reality is that mining operations often result in worse conditions after the conclusion of the operations, than existed before mining began. ${ }^{111}$ The context has and continues to be exploitative by design and as such companies not only contribute to creating poverty but actively 'bank on it'. ${ }^{112}$ While a commission of inquiry into the Marikana massacre was held, its scope was limited to state accountability and again no consequences followed for the companies involved. ${ }^{113}$

It is clear from this historical context in South Africa that companies have been instrumental in establishing legal systems that justify their own operations in jurisdictions in which they continue to cause systemic harms. There is no radical break from the colonial interests that first created them. Given this far-reaching and ongoing harm, the contemplation of accountability requires a closer look at the actor/s involved.

\section{Remembering the Actors Behind the Company}

The state and company are not self-animating; there is human agency behind colonial-apartheid systemic inequality. Notwithstanding this, the systemic colonial-apartheid legacy is not easily attributable to human actors, due to the mutually constituting and legitimating force of the law and legal personality as sovereign and company.

Even when the political control of the state was transferred to a democratically elected government, no equivalent transfer of power occurred with companies. Given the notably symbiotic relationship between state and company during the colonial-apartheid era, this absence speaks volumes. The nature of the juristic person is such that the human beings behind them, whether collectively or in syndicate, are insulated from accountability. As such, it is not surprising that the company has retained its colonial-apartheid trajectory and relationship to systemic inequality.

This has two implications. The first is that no direct accountability for the systemic harm of colonial-apartheid is possible without looking at past juristic personality to recognize that it was not in fact the company or the state that were responsible for and benefiting from these abuses but ultimately human beings. ${ }^{114}$ This does not seek to essentialize the complexity of organizational or group dynamics, but rather draw attention to the fact that there are non-abstract, actual actors, with interpersonal dynamics, that ought to be considered in determining accountability. The second is that the construct, particularly the company, continues to operate as if it is a neutral instrument and thereby obfuscates any interrogation into either its legitimate existence/recognition or the agency and accountability of the human actors behind it, their ideological commitments and the impact that this will have on the continuation of systemic inequalities and harms.

It has been suggested that '[c]loser examination of the relationship between wage income and corporate profits in the composition of inequality in South Africa is needed - rather than just the contribution of profits to personal income. ${ }^{115}$ This would facilitate a more clearly

\footnotetext{
${ }^{110}$ Madlingozi, note 35, 138-9; Morgan Ndlovu, 'Living in the Marikana World: The State, Capital and Society' (2013) 8:1 International Journal of African Renaissance Studies 46, 47-8.

111 Bonita Meyersfeld, 'Empty Promises and the Myth of Mining: Does Mining Lead to Pro-Poor Development?' (2017) 2:1 Business and Human Rights Journal 31, 33, 50.

112 Ibid.

${ }^{113}$ Marikana Commission of Inquiry, 'Report on Matters of Public, National and International Concern Arising Out of the Tragic Incidents at the Lonmin Mine in Marikana, in the North West Province' (2015), https:// www.gov.za/sites/default/files/gcis_document/201506/38978gen6993.pdf (accessed 16 November 2021).

114 Deiser, note 11, 228-9.

${ }^{115}$ UNDP, The Impacts of Social and Economic Inequality on Economic Development in South Africa (New York: UNDP, 2014) 34 .
} 
evidenced picture of how inequality contributes to poverty and, more pertinently, what policy interventions are necessary to avert this. This is, however, made difficult due to the complexities of corporate structures and the distribution of profits along with the legally sanctioned lack of transparency that is facilitated by the juristic personality of the company. Furthermore, the narrative that sanitizes the objectives of a company as being the simple pursuit of profit obscures the violent interests of the corporation in maintaining systemic poverty and inequality in order to continue to accumulate and maintain wealth and power. Therefore, the role of the company in creating and sustaining poverty and inequality is not interrogated and neither are the humans responsible for, and benefiting from, these dynamics.

\section{Re-evaluating the Utility of the Company as a Subject}

It has been widely submitted that the company was designed to provide for the consolidation of capital to support the entrepreneurial ventures of individuals or groups of individuals; and that this is good for society as it develops the economy. ${ }^{116}$ The incentive of shareholders to invest is regarded as the limitation of risk to the initial investment and the potential for growth.

Part of this logic is that the company attracts investors whose pursuit of profit propels the economy. South Africa has been no exception in the uptake of the notion that the primary purpose of a company is profit maximization for the good of the economy. ${ }^{117}$ Accordingly, in alignment with international economic orthodoxy, the primacy of shareholder interests was secured through the application of the shareholder value doctrine. ${ }^{118}$ This has largely absolved the company of obligations beyond profit maximization within the parameters of legal compliance. ${ }^{119}$

Although it has long been held that the interests of the company should mirror the interests of its shareholders, the interests of other stakeholders such as creditors, employees and affected communities may be regarded as relevant to shareholder interests. ${ }^{120}$ The goodwill and market value of the company is an asset that can be impacted by these additional stakeholders and this has become known as the enlightened shareholder value approach. ${ }^{121}$ Nonetheless, the prevailing position is that the interests of the shareholders as a collective, that is the interest of profit maximization as the driving purpose of the company, should take priority over other competing interests. This profit-seeking motive combined with the limited exposure to risk has been used to explain the granting of legal personality. ${ }^{122}$ It has been argued that this explanation tends towards a description of what juristic personality enables rather than a substantive explanation as to why it is conferred. ${ }^{123}$

\footnotetext{
${ }^{116}$ Vermaas M Hahlo, South African Company Law Through the Cases, 6th edn (Cape Town: Juta \& Co, 1999) 1; Judith Katzew, 'Crossing the Divide between the Business of the Corporation and the Imperatives of Human Rights - The Impact of Section 7 of the Companies Act 71 of 2008' (2011) 128 South African Law Journal 686, 694.

117 Baird and Henderson, note 13, 1323-4; Friedman, note 13, 112; Hahlo, note 116, 4.

118 Ibid; Steve Denning, 'The Origin of “The World's Dumbest Idea”: Milton Freedman', Forbes (26 June 2013), https://www.forbes.com/sites/stevedenning/2013/06/26/the-origin-of-the-worlds-dumbest-idea-milton-fried man/?sh=5871acce870e (accessed 16 November 2021).

${ }^{119}$ Friedman, note 13, 112; Hahlo, note 116, 4.

${ }^{120}$ Cassim, note 5, 20.

${ }^{121}$ Ibid.

${ }^{122}$ David Bilchitz, 'Corporate Law and the Constitution: Towards Binding Human Rights Responsibilities for Corporations' (2008) 125 South African Law Journal 754, 756.

${ }^{123}$ Samaradiwakera-Wijesundara, note 16, 194-6.
} 
Pope Innocent IV propounded the doctrine, as well as the notion of the divine right to conquest, which was observed as authoritative by latter Roman and Dutch jurists. ${ }^{124}$ Not many corporate bodies were commercial then as the concept was created to allow perpetual succession of religious office and property. ${ }^{125}$ Shifting dynamics of the source of power and the seat of authority of the sovereign impacted the concept of juristic personality. ${ }^{126}$ The rise of the secular state centralized authority, drawing it away from religious bodies. ${ }^{127}$ Legal personality became a construct granted as a concession of power by the state. Frederic W Maitland observes that it was granted initially as a 'gift' or 'privilege' by the sovereign. ${ }^{128}$ This served as a control mechanism over collectives that may have grown to compete with and possibly threaten the state's hegemony. ${ }^{129}$ This threat was neutralized by making any collectives that were not expressly authorized by the state charter of incorporation illegal. ${ }^{130}$ This crystallised the concept of the anthropomorphic fictitious (legal) person that was permitted to hold property, while veiling the natural persons acting as or on its behalf from personal liability. ${ }^{131}$ Thus, the juristic person joined the ranks of the individual human as the social unit from which all other relations are understood within the Western philosophical canon. ${ }^{132}$

That the company as a (legal) person was made in the image of a person is normatively laden. At the time that the (legal) personality of the company was first recognized, personhood had a very specific profile. This is that of the white man. ${ }^{133}$ Juristic personality thus may be argued to be steeped in colonial subjectivity. McClintock describes this as possessive individualism that constituted itself by positioning women and black people as subordinate. ${ }^{134}$ This humanist individual conception necessarily excluded communitarian and dynamic conceptions of the self. ${ }^{135}$ Attendant to the use of force to perpetuate this version of selfhood and personhood was the "tactful squadrons of moral teachers, advisers and bewilderers to coax the colonized into admitting the legitimacy and "universality" of the rulers' values.' ${ }^{136}$ This process of colonization has been so effective that the ideology underpinning the company has gone largely uninterrogated and unchanged.

There were other ways of serving the purported purpose of juristic personality rather than building an individualized, legal person with the sole goal of profit-making. That is the purpose of acting as a collective with common purpose or towards a common goal; potentially including the goal of pooling resources towards maximizing profit. According to Paddy Ireland, the company remained the exception rather than the norm for mobilizing resources, granted as a privilege rather than a legal entitlement from the close of the 18 th century to the early 19 th century. ${ }^{137}$

\footnotetext{
${ }^{124}$ Dewey, note 4, 655.

${ }^{125}$ Edward Cavanagh, 'Corporations and Business Associations from the Commercial Revolution to the Age of Discovery: Trade, Jurisdiction and State, 1200-1600' (2016) 14:10 History Compass 493, 495.

${ }^{126}$ Dewey, note 4, 656.

127 Ibid.

128 Maitland, note 4, 197.

129 Ibid.

130 Ibid.

131 Pistor, note $15,65$.

${ }^{132}$ Linda Tuhiwai-Smith, Decolonising Methodologies: Research and Indigenous Peoples (Dunedin: University of Otago Press, 1999) 48.

133 Ibid, 15.

${ }^{134}$ McClintock, note 63, 314.

135 Ibid, 317.

136 Ibid, 333.

${ }^{137}$ Ireland, note 9, 839.
} 
Adam Smith expressed reservations about the company. He stated that the company with distinct legal personality is inefficient. ${ }^{138}$ He characterized the design of the company as essentially one that enables rent-seeking by shareholders, who need do nothing but invest money, and opportunism by directors, who are paid for managing investors' money with a view to simply making more. ${ }^{139}$ This is essentially parasitic behaviour that does not advance society economically but rather gains from historical wealth accumulation. ${ }^{140}$ In terms of this, ${ }^{141}$

[T] he focus on rents relates to the private capture of value from assets such as natural resources that should accrue to society as a whole, but the term "rents" has come to apply to any context in which a benefit is secured for less than its real value with rentseeking behavior focused on the attempt to do just this, usually using forms of political leverage or monopoly power ... this incentivizes a focus on such capture rather than on productive investment or innovation, with potentially negative impacts on economic development.

Therefore, companies are not necessarily more socially efficient business entities. The company is not inexorably an instrument for economic development and thus its recognition is not automatically valid and necessary. Joel Bakan critiques the notion that 'the business of business is business' as a justification for the prioritization of profit as morally neutral and economically legitimate. ${ }^{142}$ He argues that prioritizing profit in this manner is pathological and inherently dangerous as it facilitates anti-social behaviour that would be morally and legally reprehensible if displayed by human beings. ${ }^{143}$ In light of this contention, I turn to consider in more detail what the consequence of (legal) personality and 'limited liability', simultaneously elides and enables.

\section{A Perverse Purpose: Sanitizing the Perpetuation of Systemic Inequality With Limited Liability}

Theoretically, liability of shareholders and directors of a company is limited because the liability vests in the (legal) person of the company. ${ }^{144}$ However, there is no such person. Furthermore, defining the conduct of the company, given the varying organizational structures and multiplicity of human actors, for the purposes of establishing liability is not a straightforward task. This is further complicated by the reality that separate legal personality means that holding or parent companies are generally distinct from their subsidiaries.

A nebulous matrix of beneficiaries, acting across vast territories and jurisdictions, is created, which renders the allocation of responsibilities and accountability for corporate harms virtually impossible. ${ }^{145}$ As mentioned, this is not unexpected considering that a

\footnotetext{
${ }^{138}$ Adam Smith, An Inquiry into the Nature and Causes of the Wealth of Nations (Petersfield: Harriman House, 2007) 573-4.

${ }^{139}$ Ibid.

140 Ibid, 586-7; Paddy Ireland, 'Property and Contract in Contemporary Corporate Theory' (2003) Legal Studies $453,480-1$.

${ }^{141}$ UNDP, note 115, 15-6 (emphasis added).

${ }^{142}$ Friedman, note 13, 112.

${ }^{143}$ Joel Bakan, The Corporation: The Pathological Pursuit of Profit and Power (New York: Free Press, 2004) 2, 158.

144 Salomon v A Salomon \& Co Ltd, note 9, 35, 57; Dewey, note 4, 673; Deiser, note 11.

145 Jeroen Veldman and Martin Parker, 'Spectres, Inc: The Elusive Basis of the Corporation' (2012) 117:4 Business and Society Review 413, 416.
} 
fundamental characteristic of the company is distinct (legal) personality. ${ }^{146}$ This design enables limited liability of the shareholders of the company; which shields its human actors and beneficiaries from accountability. ${ }^{147}$ Companies can be liquidated and leave no actor to pursue when harm manifests. ${ }^{148}$ The practical reality is, however, that liability cannot be limited in the abstract and is inevitably displaced onto something or someone else. This occurs by design.

Ownership of shares continues to reside predominantly in the control of the wealthiest people. ${ }^{149}$ This reveals an 'economic system that facilitates the privatisation of gains in the hands of ever smaller elites while also socialising risks'. ${ }^{150}$ I have shown how this systemic inequality is racialized and gendered. So are its impacts. Displaced liability does not vest in the fictional person or disappear into the ether, but is passed on to other human beings. The effect of limited liability and its factual displacement is that those who benefit from the generation of social risk through the singular pursuit of profit are not accountable when these risks manifest as harms to society. ${ }^{151}$ This dangerous behaviour is sanitized through the recurrent narrative of the moral neutrality of the company and the veil that separates the human actors from the distinct (legal) person of the company. ${ }^{152}$

\section{Conclusion: Reclaiming Subjectivity}

The instrument of the company facilitates a process of racialized and gendered exploitation that is masked, neutralized and naturalized as profit maximization. In the words of Beth Stephens, 'the pursuit of profit is, by definition, an amoral goal - not necessarily immoral, but rather morally neutral. ${ }^{153}$

I draw on Pumla Gqola's contemplation 'what new meanings are inevitably uncovered when we ask questions differently?' ${ }^{154}$ Rather than question how to hold companies liable for human rights violations and systemic poverty and inequality, we must ask why human beings are allowed to cause harms and avoid accountability that they otherwise would not be able to cause and avoid as individuals. Thus, I embarked on an interrogation of the legal fiction/construct of juristic personality.

Situating my analysis in South Africa, I have attempted to connect the recognition of the (legal) personality to continued racialized and gendered poverty and inequality. I contextualized this through a critically revised narrative of the symbiotic relationship between the company and the colonial state. I argued that read in this context, subjectivity and (legal) personhood is implicated in the ideology that creates and perpetuates racist, patriarchal and impoverishing categories and hierarchies; while simultaneously shielding from accountability the human actors who have designed them in their interests.

As such, I contend that efforts to hold companies accountable for human rights violations, and particularly one concerned with a gendered approach, should begin with the fundamental question of the entitlement of companies to (legal) personality and the legitimate parameters of company power. As the company is brought into existence by the legal imagination, if there is the necessary will to do so it may be also be curtailed by the law.

\footnotetext{
${ }^{146}$ Salomon v A Salomon \& Co Ltd, note 9, 35, 57; Dewey, note 4, 673; Ireland, note 9, 839.

147 Smith, note $138,586-7$.

148 Ireland, note 9, 830.

149 Blankenburg et al, note 14,852 .

150 Ibid, 821.

${ }^{151}$ Ireland, note 9, 852.

152 Beth Stephens, 'The Amorality of Profit: Transnational Corporations and Human Rights' (2002) 45 Berkeley Journal of International Law 45, 46.

153 Ibid, 46.

154 Gqola, note 19, 84.
} 
This fundamentally shifts the dynamics of power from one where a concession is sought from companies to guard against harm; to one where the very access to and exercise of power must be justified. In this way, I call for the reclamation of the authority to name and determine the content of subjectivity and its systemic consequences on being in the world beyond (legal) personhood.

Conflicts of interest. The author declares none.

Funding. There is no funding to declare. 